\title{
The pattern of craniofacial encephalocel in Bethel Teaching General Hospital, Addis Ababa, Ethiopia
}

Tesfaye Mulat

From Hydrocephalus 2015

Banff, Canada. 18-21 September 2015

Craniofacial encephaloceles are commonly seen birth defects. The incidence is 1 in every 100, 000 live births. Six patients with craniofacial encephaloceles are treated by a combined craniofacial approach. The corrective measure allows reduction of the herniated encephalocele and correction of the craniofacial deformity in the same operation procedure.

All cases admitted from May 2013 until June 13, 2014 to Bethel Teaching General Hospital were identified, and data were collected retrospectively, including demographics, clinical events, MRI and or CT scan findings, surgical techniques, complications and outcomes were analyzed using SPSS.

\section{Results}

See table 1.

The MRI finding in four of these patients shows only encephalocele, no hydrocephalus. In two of the cases beside the encephalocel, there is mild hydrocephalus. They need a follow up in six months. Four of the patients weight are below the standard.

All patients were doing well post operatively, no infections, bleeding or other complications.

\section{Discussions}

The surgery performed for all patients were frontal craniotomy including orbital roof was taken. Then encephalocele excision done both from facial and cranial side, followed by correction of the hypertylarism and nasal reconstruction. The surgery takes 5 to $7 \mathrm{hrs}$. The blood loss was replaces especially for the children below the age of 6 . Post operatively they stayed in intensive care unit for two days, thereafter the edema started to decreased, in a week time they were discharged.

Correspondence: tesfayeml@hotmail.com Bethel Teaching general Hospital, Ethiopia

\begin{tabular}{lllll}
\multicolumn{2}{l}{ Table $\mathbf{1}$} & & \\
\hline Age & Sex & Origin & MRI & Outcome \\
\hline 5 & M & Amahara (wollo) & No Hydrocephalus & Good \\
10 & M & Oromiya (Harar) & Mild Hydrocephalus & Good \\
5 & M & Oromiya (Nazerat) & Mild Hydrocephalus & Good \\
1.5 & M & Oromiya (Harar) & No Hydrocephalus & Good \\
14 & M & Oromiya (Harar) & No Hydrocephalus & Good \\
18 & M & Oromiya (harar) & No Hydrocephalus & Good
\end{tabular}

Four of the patients were from Oromiya region, the reason is that they were brought by NGO who are working in that region.

\section{Conclusion}

Even though craniofacial encephalocel seems rare in Western countries, it is not rare in this country. One of the reasons could be due to lack of Vit. B during pregnancy. This vitamin is essential for timely closure of the cranial bones. All of these patients are coming from the rural Ethiopia in very low socioeconomic where there is no antenatal care, most of the patients are malnourished. If we provide Vit. B during pregnancy we may reduce the incidence of this pathology.

\section{Consent to publish}

Written informated consent for publication of their clinical details was obtained from the patient/parent/guardian/ relative of the patient.

Published: 18 September 2015

\section{References}

1. Mulat Tesfaye, Salemark OLars: Description of patients admitted to Yekatit Hospital, Addis Ababa, Ethiopia, Published in the Ethiopian Medical Journal. Ethiopia EMJ 2006, 44(4):369-375, Description of patients admitted to a burn unit of Yekatiti 12 Hospital Addis Ababa. 
2. Awareness of Burns among high school students in Addis Ababa,

Ethiopia Submitted to the Ethiopian Medical Journal.

3. Burns in Ethiopia., thesis paper in University of Bergen, Norway.

doi:10.1186/2045-8118-12-S1-P37

Cite this article as: Mulat: The pattern of craniofacial encephalocel in Bethel Teaching General Hospital, Addis Ababa, Ethiopia. Fluids and Barriers of the CNS 2015 12(Suppl 1):P37.

Submit your next manuscript to BioMed Central and take full advantage of:

- Convenient online submission

- Thorough peer review

- No space constraints or color figure charges

- Immediate publication on acceptance

- Inclusion in PubMed, CAS, Scopus and Google Scholar

- Research which is freely available for redistribution

Submit your manuscript at www.biomedcentral.com/submit 